\title{
Adsorption of Copper, Zinc, and Nickel Using Loesses as Adsorbents by Column Studies
}

\author{
Pongsakorn Punrattanasin ${ }^{1 *}$, Panha Sariem ${ }^{2 * *}$ \\ 'Research Center for Environmental and Hazardous Substance Management, Khon Kaen University, \\ ${ }^{2}$ Department of Civil Engineering, Faculty of Engineering, Khon Kaen University, \\ 123 Moo 16 Mittapap Road, Nai-Muang, Muang District, Khon Kaen 40002, Thailand
}

Received: 27 September 2014

Accepted: 18 January 2015

\begin{abstract}
The adsorption behaviors of copper $(\mathrm{Cu})$, zinc $(\mathrm{Zn})$, and nickel $(\mathrm{Ni})$ on red and yellow loesses in Khon Kaen were evaluated by applying small-scale column studies. Continuous flows with the constant flow rate of the influents were consecutively implemented within three different cycles: adsorption, desorption, and adsorption processes. The results illustrated that the adsorption capabilities between cycles I and III were found to be significantly different. The adsorption process in cycle I appeared to be more effective than cycle III due to the availability of more adsorption site and the incomplete desorption of the metal ions from the adsorbent surface. The experimental and theoretical analyses showed that adsorption capacities were in the order of $\mathrm{Cu}<\mathrm{Zn}<\mathrm{Ni}$, while yellow loess consisted of the highest adsorption capacity. The Thomas and YoonNelson models can predict the adsorption behaviors in this study.
\end{abstract}

Keywords: loess, adsorption, small-scale column, desorption

\section{Introduction}

Water pollution by heavy metal ions is thought to be on list of main environmental concerns because of its harmful impact on the ecosystem and public health [1]. The excessive rate of heavy metal concentration in the water causes a critical threat to health due to its non-degradability and toxicity [2]. $\mathrm{Cu}, \mathrm{Ni}$, and $\mathrm{Zn}$ are reported to being used in the mining, metallurgical, electroplating, and galvanization industries [3-5]. The effluents of these industries into the water commonly lead to adverse ecological problems and serious toxicological concerns. More proactive action in tackling the removal of heavy metal ions should be impressively necessitated for the sustainable uses of water in the future.

Several physiochemical and biological processes, including adsorption, filtration, chemical precipitation,

*e-mail: ponpun@kku.ac.th

**e-mail: sariem.panha@yahoo.com chemical oxidation and reduction, ion exchange, and electrochemical treatment have been developed to remove the dissolved heavy metals, dyes, phosphate, and nitrate from water and wastewaters $[6,7]$. Most of these conventional methods consist of high operational maintenance costs, incomplete metal removal, high energy requirements and the generation of toxic residual metal sludge [8, 9]. Adsorption offers more benefits in terms of viability, availability, profitability, simplicity of operation, and good environmental aspect $[10,11]$. Adsorption in column by means of continuous flow operations is generally desired to purify the wastewater due to its static treatment and efficiency [12, 13]. Small-scale column studies are generally performed to determine the accurate prediction of heavy metal ion removal and to represent its adsorption capability in wastewater treatment.

Activated carbons have been broadly used as adsorbents for wastewater purification. Its high cost motivates the researchers to discover new and inexpensive materials for wastewater treatment. Several soils, named CL-ML2 
and SM1, were previously selected as the adsorbent of column adsorption test [14]. The adsorption capacities of loesses in Khon Kaen were primarily studied by the batch adsorption test [15]. Though the batch adsorption test could offer beneficial evidence on the application of the metal adsorption, column adsorption studies could provide the most practical application of this process. The column adsorption experiment was closer to the tangible circumstances than the batch adsorption experiment. The adsorption behaviors of loesses in Khon Kaen by the column adsorption remain unidentified. The objective of this study is to investigate the adsorption capability of $\mathrm{Cu}, \mathrm{Zn}$, and $\mathrm{Ni}$ on red and yellow loesses by small-scale column studies.

\section{Materials}

\section{Adsorbents}

Yellow loess and red loess in Khon Kaen were selected as the adsorbents in this study. The bulk samples were dug at a depth of $50 \mathrm{~cm}$ from its surfaces and in various zones based on their presence in the province. Loess deposits are abundantly found in Khon Kaen from a few to more than six meters above the water table [16]. The process to remove the bulk water from the samples was followed by oven-drying at $110^{\circ} \mathrm{C}$ for 24 hours. The designated adsorbents for the column adsorption test were then sieved through $0.425 \mathrm{~mm}$. The surface of the adsorbent grains were found to be smooth and sub-rounded [16]. Small clay content was presented in the form of clay bridge bonds [17]. The basic and engineering properties of the adsorbents are listed in Table 1 [15].

\section{Adsorbates}

$\mathrm{Cu}, \mathrm{Ni}$, and $\mathrm{Zn}$ were used to represent the range of common heavy metals in the wastewater. Their adsorption behaviors on the red and yellow loesses were investigated by performing continuous flow. The concentration of the influents was designated to be $500 \mathrm{mg} / \mathrm{L}$ and obtained by dissolving the stock solution with the concentration of 100 $\mathrm{g} / \mathrm{mL}$ into the deionized water. The properties of heavy metal solutions are shown in Table 2 [15].

\section{Experimental Procedure}

\section{Characterization of Adsorbents}

The morphology of the surface of loesses particles was examined by a scanning electron microscope (S-3000N, Hitachi, Japan). The chemical contents of the adsorbents were verified by $\mathrm{x}$-ray fluorescence (XRF). The specific surface area, total pore volume, and mean pore diameter were measured by ASAP-2010 following BrunauerEmmett-Teller (BET) adsorption theory [15]. The natural $\mathrm{pH}$ of the adsorbents was determined using a $\mathrm{pH}$ meter with proper calibration. A sample of natural $\mathrm{pH}$ test is defined by
Table 1. Basic and engineering properties.

\begin{tabular}{|l|c|c|}
\hline \multicolumn{1}{|c|}{ Basic and engineering properties } & $\begin{array}{c}\text { Yellow } \\
\text { Loess }\end{array}$ & $\begin{array}{c}\text { Red } \\
\text { Loess }\end{array}$ \\
\hline$\%$ Passing No. 200 sieve & 12.26 & 11.71 \\
\hline \% Passing No. 4 sieve & 93.18 & 96.45 \\
\hline Liquid Limit LL (\%) & 30.20 & 18.03 \\
\hline Plastic Limit PL (\%) & 20.60 & 13.00 \\
\hline Plasticity Index PI (\%) & 6.60 & 5.03 \\
\hline USCS Symbol & $\mathrm{SC}$ & $\mathrm{SM}$ \\
\hline Specific Gravity G & 2.63 & 2.68 \\
\hline Max. Dry Density (g/cm $\left.{ }^{3}\right)$ & 1.87 & 2.00 \\
\hline Coefficient of Permeability k (cm/s) & $2.27 \times 10^{-6}$ & $4.0 \times 10^{-6}$ \\
\hline
\end{tabular}

Table 2. Properties of heavy metals.

\begin{tabular}{|l|c|c|c|}
\hline \multicolumn{1}{|c|}{ Properties } & $\begin{array}{c}\text { Copper } \\
\text { Nitrate }\end{array}$ & $\begin{array}{c}\text { Nickel } \\
\text { Nitrate }\end{array}$ & $\begin{array}{c}\text { Zinc } \\
\text { Nitrate }\end{array}$ \\
\hline Formula & $\mathrm{Cu}\left(\mathrm{NO}_{3}\right)_{2}$ & $\mathrm{Ni}\left(\mathrm{NO}_{3}\right)_{2}$ & $\mathrm{Zn}\left(\mathrm{NO}_{3}\right)_{2}$ \\
\hline Molecular weight $(\mathrm{g} / \mathrm{mol})$ & 241.60 & 290.80 & 297.50 \\
\hline Density $\left(\mathrm{g} / \mathrm{cm}^{3}\right)$ & 2.32 & 2.05 & 2.06 \\
\hline Solubility $(\mathrm{g} / 100 \mathrm{ml})$ & 137.80 & 94.20 & 184.30 \\
\hline
\end{tabular}

mixing $10 \mathrm{~g}$ of the oven-dried and sieved soil with $10 \mathrm{~mL}$ of deionized water in a graduated beaker. The mixture was stirred for 1 minute using plastic spoons and then left one hour before the $\mathrm{pH}$ measurement. The approved $\mathrm{pHna}$ of the adsorbent was the average $\mathrm{pH}$ of three samples of natural $\mathrm{pH}$ test.

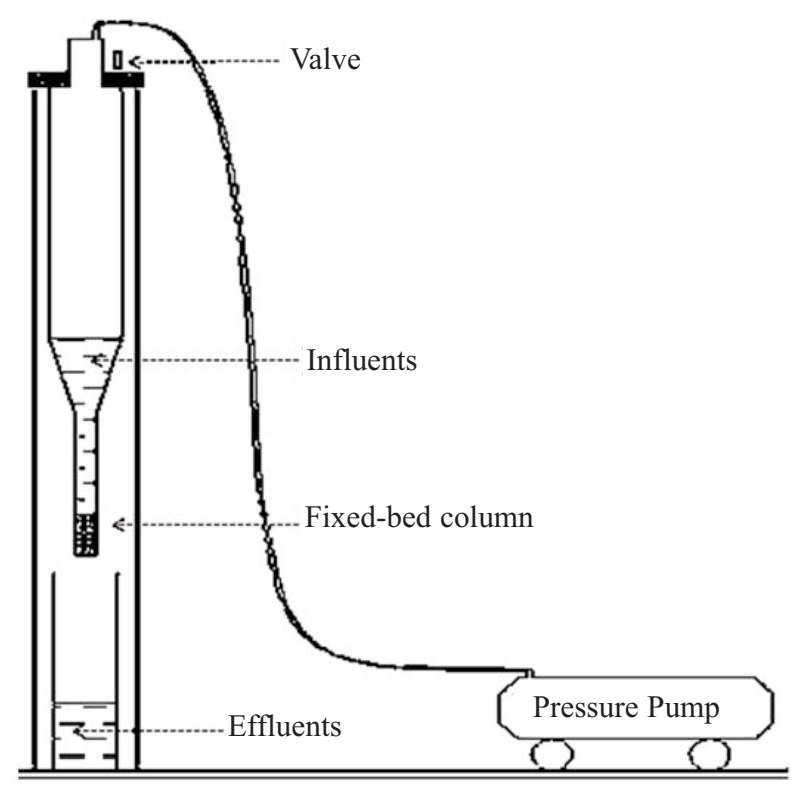

Fig. 1. Schematic drawing of column adsorption components. 
Table 3. Scope of column adsorption test.

\begin{tabular}{|l|c|}
\hline \multicolumn{1}{|c|}{ Parameters } & Description \\
\hline Adsorbents & Red Loess-Yellow Loess \\
\hline Adsorbates & $\mathrm{Cu}\left(\mathrm{NO}_{3}\right)_{2}-\mathrm{Zn}\left(\mathrm{NO}_{3}\right)_{2}-\mathrm{Ni}_{\left(\mathrm{NO}_{3}\right)_{2}}$ \\
\hline Mass of adsorbents $\mathrm{m}(\mathrm{g})$ & 30 \\
\hline Flow rate $Q(\mathrm{~mL} / \mathrm{min})$ & 0.5 \\
\hline Initial concentration $C_{0}(\mathrm{mg} / \mathrm{L})$ & 500 \\
\hline
\end{tabular}

\section{Procedure of Column Adsorption Test}

The components of the column adsorption apparatus are described in Fig. 1. PVC tubes with an internal diameter of $1.2 \mathrm{~cm}$ and height of $3 \mathrm{~cm}$ were used as a fixed-bed column. Adsorbents with mass of $30 \mathrm{~g}$ were packed and compacted in the fixed-bed column according to Standard Proctor Test before conducting the flowing process. The energy of the compaction of the samples was equal to the Standard Proctor Test. The number of blows was equivalently calculated based on the condition of the artificial hammer. The selected influents in this study were solutions of copper nitrate $\left(\mathrm{Cu}\left(\mathrm{NO}_{3}\right)_{2}\right)$, zinc nitrate $\left(\mathrm{Zn}\left(\mathrm{NO}_{3}\right)_{2}\right)$, and nickel nitrate $\left(\mathrm{Ni}\left(\mathrm{NO}_{3}\right)_{2}\right)$ at concentrations of $500 \mathrm{mg} / \mathrm{L}$. The red and yellow loesses were employed as the adsorbent in the fixed-bed column. The scope of these column studies is summarized in Table 3.
The entire procedure of the experiment was designated to be completed within three different cycles. Cycles I, II, and III were successively carried out to investigate the adsorption process of the heavy metal ions, to evaluate the desorption behavior of the distilled water after the adsorption process, and to verify adsorption capability after the desorption process. The procedure of column adsorption is briefly described in Fig. 2.

The flowing processes of each cycle were at least finalized until the exhaustion period of the adsorbents. The flow rate of the influents was designated to be equal to $0.5 \mathrm{~mL} / \mathrm{min}$. The pressure pump was used to drive a pressure of 35 psi into the PVC tube in order to stabilize this flow rate. The volume of the effluent solution $\left(V_{\text {eff }}\right)$ was periodically collected and measured by the graduated beaker conforming to the service time $(t)$. A chronometer was employed to measure the service time $(t)$ at different collections of effluents. The effluents were diluted with $1 \%$ of nitric acid $\left(\mathrm{HNO}_{3}\right)$ to adapt the atomic analysis spectrometer detection limit. A Perkin Elmer-200 (Germany) atomic analysis spectrometer functioning with an air acetylene flame was used to measure the concentration of the effluents. The calibration curve of each heavy metal was plotted based on its wavelength and standard solutions. The concentration of the effluents $\left(C_{t}\right)$ could finally be identified and the adsorption behavior of this column adsorption study can be interpreted by the "Breakthrough curves."

\begin{tabular}{|c|}
\hline Compaction of adsorbent $m=30 \mathrm{~g}$ \\
\hline Cycle I \\
Flow of influent in fix-bed column \\
$C_{0}=500 \mathrm{mg} / \mathrm{L}$ \\
$Q=0.5 \mathrm{~mL} / \mathrm{min}$ \\
$\square$ \\
Cycle II \\
Flow of Distilled water \\
$C_{0}=0.00 \mathrm{mg} / \mathrm{L}$ \\
$Q=0.5 \mathrm{~mL} / \mathrm{min}$ \\
$\square$ \\
Cycle III \\
Flow of influent in fix-bed column \\
$C_{0}=500 \mathrm{mg} / \mathrm{L}$ \\
$Q=0.5 \mathrm{~mL} / \mathrm{min}$
\end{tabular}
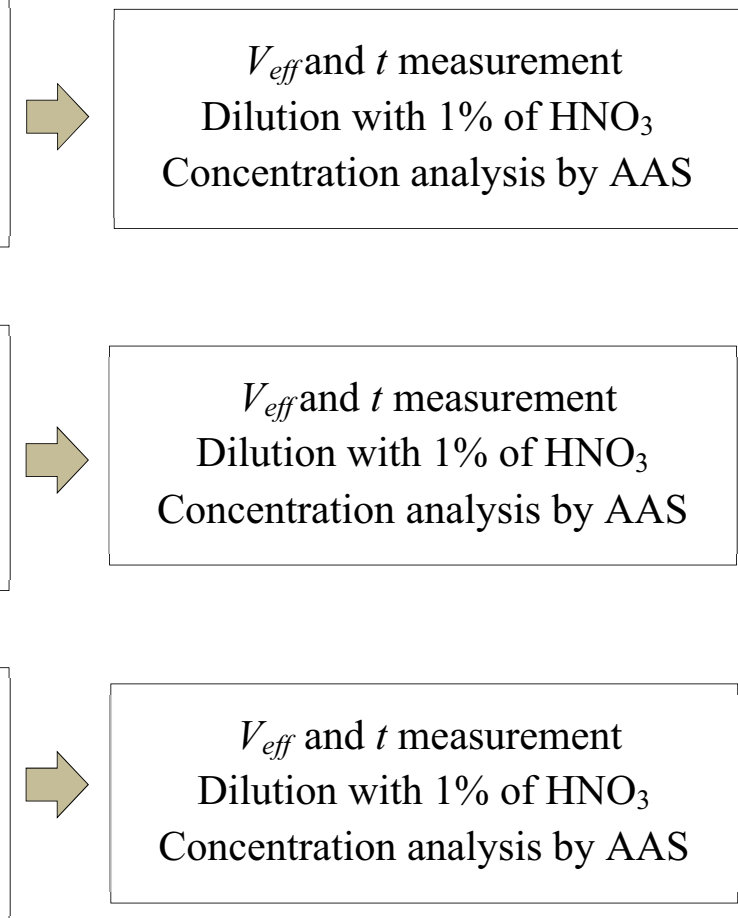

Fig. 2. Procedure of column adsorption test. 
Table 4. Basic parameters of adsorbents.

\begin{tabular}{|l|c|c|}
\hline \multicolumn{1}{|c|}{ Parameters } & $\begin{array}{c}\text { Yellow } \\
\text { Loess }\end{array}$ & $\begin{array}{c}\text { Red } \\
\text { Loess }\end{array}$ \\
\hline Specific surface area $S_{B E T}\left(\mathrm{~m}^{2} / \mathrm{g}\right)$ & 18.84 & 8.00 \\
\hline Total pore volume $V_{T}\left(\mathrm{~cm}^{3} / \mathrm{g}\right)$ & 0.042 & 0.048 \\
\hline Mean pore diameter $D_{P}(\mathrm{~nm})$ & 9.07 & 24.40 \\
\hline Natural $\mathrm{pH} p H_{n a}$ & 6.58 & 6.70 \\
\hline
\end{tabular}

\section{Results and Discussion}

\section{Characterization of Adsorbents}

The result of X-Ray Fluorescence demonstrated that the percentage of the silicate oxide $\left(\mathrm{SiO}_{2}\right)$, the aluminum oxide $\left(\mathrm{Al}_{2} \mathrm{O}_{3}\right)$, and the ferric oxide $\left(\mathrm{Fe}_{2} \mathrm{O}_{3}\right)$ were mainly found in the total weight. The amounts of the $\mathrm{SiO}_{2}$ in yellow and red loesses were respectively $76.20 \%$ and $73.80 \%$, while red loess of China contained $68.83 \%$ of $\mathrm{SiO}_{2}$ [18]. This eventually shows that $\mathrm{SiO}_{2}$ principally covers the entire chemical composition.

The second rank of chemical compositions in those adsorbents were followed by the $\mathrm{Al}_{2} \mathrm{O}_{3}$. The chemical contents of both adsorbents are presented in Fig. 3. The surfaces of red and yellow loesses particles were magnified 5,000 times to inspect their heterogeneities and were separately illustrated in Figs. 4 (a) and (b). It was obviously seen that the surface of the yellow loess was rougher than the red one. The basic parameters of the micro-structure of adsorbents in this study and their natural $\mathrm{pH}$ are additionally provided in Table 4. The specific surface areas of yellow and red loesses were $18.84 \mathrm{~m}^{2} / \mathrm{g}$ and $8.00 \mathrm{~m}^{2} / \mathrm{g}$, respectively [15].

\section{Breakthrough Analysis}

The performance of the fixed-bed column is particularly illustrated by the breakthrough curves. The breakthrough time and the shape of the breakthrough curve were utterly significant features to define the operation and dynamic

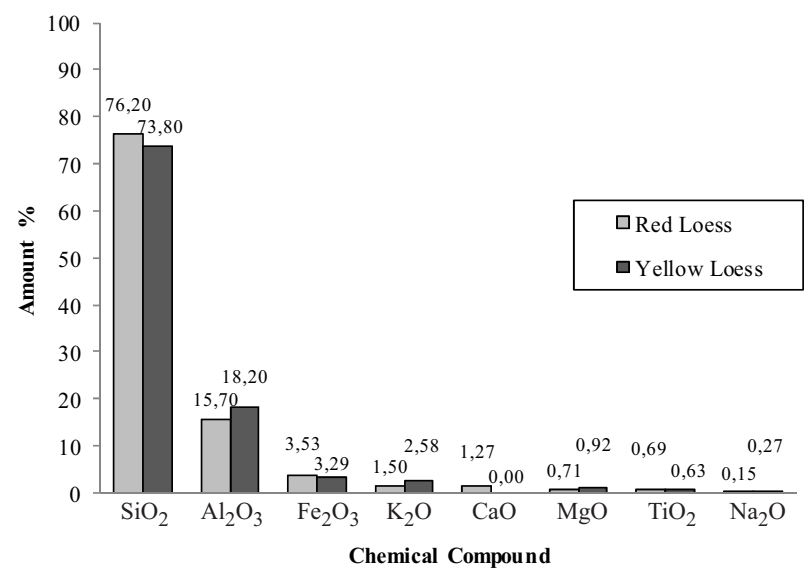

Fig. 3. Content of chemical compound of adsorbents.
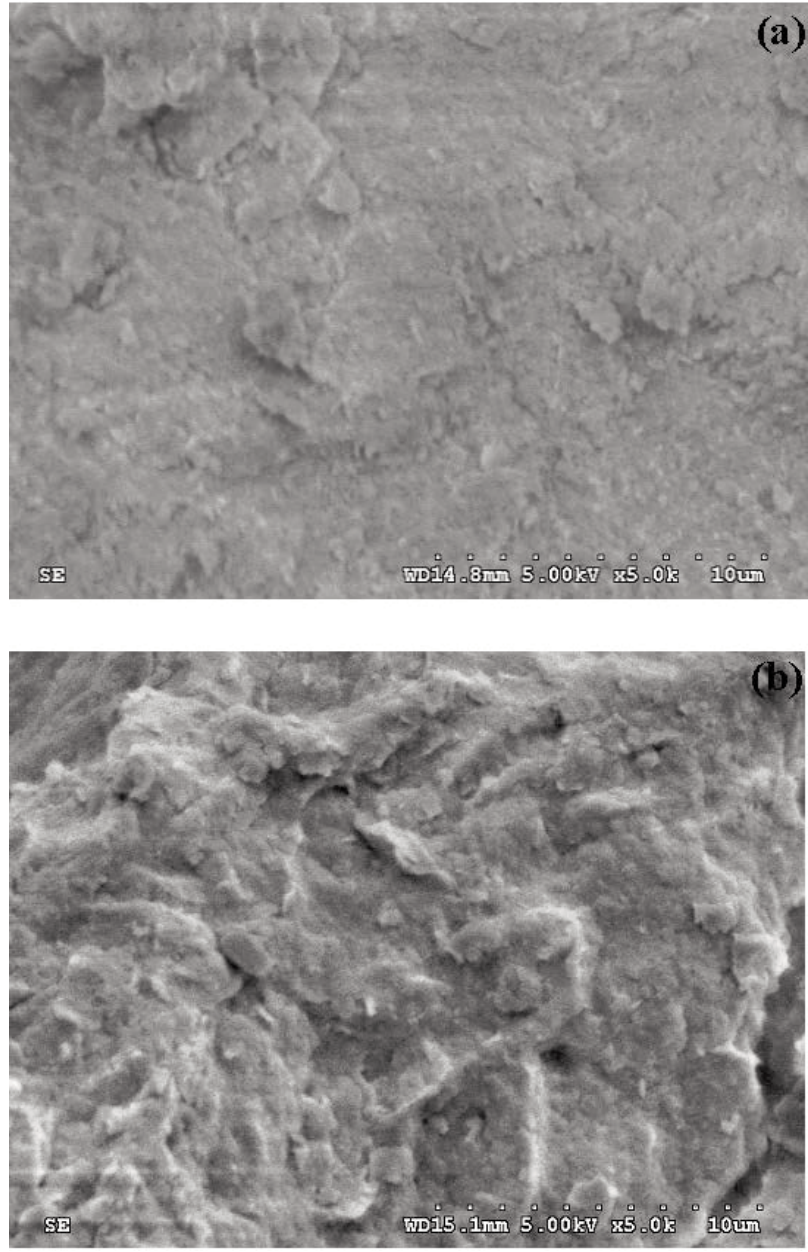

Fig. 4. Red Loess (a) and Yellow Loess (b) with magnification of 5000 Times.

response of an adsorption column [19, 20]. The typical breakthrough curve is usually represented by plotting $C_{\text {effluent }}$ or $C_{\text {effluent }} / C_{\text {inffuent }}\left(C_{t} / C_{0}\right)$ versus treated volume (V) or service time (t) [13]. The relationship between the service time ( $\mathrm{t}$ ) and the ratio of $C_{\text {effluent }}$ to $C_{\text {inffuent }}\left(C_{t} / C_{0}\right)$ represent the breakthrough curves. The breakthrough point and the point of exhaustion of the column of breakthrough curves were correspondingly selected to be the point at which $C_{t} / C_{0}=5 \%$ and $C_{t} / C_{0}=95 \%$ [11].

Figs. 5 (a), (b), and (c) describe the curves $\left(t-C_{t} / C_{0}\right)$ representing the adsorption process of $\mathrm{Cu}, \mathrm{Zn}$, and $\mathrm{Ni}$ on red (R) and yellow (Y) loesses. Three consecutive cycles (adsorption, desorption, and adsorption) were continuously performed. The breakthrough curves " $\mathrm{S}$ " were found in cycles I and III, whereas the form of curve in cycle II could not be determined. The results illustrated that the concentration of the effluents in cycle I increased sharply after the breakthrough point and then reached the point of the exhaustion of the column. This could be explained by the exit of mass transfer zone and the negligible ability to adsorb the bed [1].

The concentration of the distilled water is normally found to be null. The concentrations of the effluent samples in cycle II at the beginning of the flowing period was contrastingly found to be positive. This could be due to the 
Table 5. Parameters by experimental analysis.

\begin{tabular}{|c|c|c|c|c|c|c|c|c|c|}
\hline Metals & Loesses & Cy. & $t_{\text {total }}(\mathrm{min})$ & $V_{b}(\mathrm{~mL})$ & $q_{\text {total }}(\mathrm{mg})$ & $q_{e q(\exp )}(\mathrm{mg} / \mathrm{g})$ & $m_{\text {total }}(\mathrm{mg})$ & $Y(\%)$ & $E B C T(\mathrm{~min})$ \\
\hline \multirow{6}{*}{$\mathrm{Cu}$} & \multirow{3}{*}{ Yellow } & I & 822 & 80 & 192.97 & 6.43 & 204.01 & 94.59 & 160 \\
\hline & & II & - & - & - & - & - & - & - \\
\hline & & III & 456 & 27 & 106.51 & 3.55 & 113.17 & 94.11 & 54 \\
\hline & \multirow{3}{*}{ Red } & I & 346 & 20 & 82.13 & 2.74 & 85.87 & 95.64 & 40 \\
\hline & & II & - & - & - & - & - & - & - \\
\hline & & III & 388 & 15 & 68.11 & 2.27 & 71.48 & 95.29 & 30 \\
\hline \multirow{6}{*}{$\mathrm{Zn}$} & \multirow{3}{*}{ Yellow } & I & 1116 & 45 & 226.48 & 7.55 & 236.59 & 95.73 & 90 \\
\hline & & II & - & - & - & - & - & - & - \\
\hline & & III & 980 & 40 & 194.65 & 6.49 & 207.76 & 93.69 & 80 \\
\hline & \multirow{3}{*}{ Red } & I & 402 & 27 & 80.65 & 2.69 & 85.22 & 94.63 & 54 \\
\hline & & II & - & - & - & - & - & - & - \\
\hline & & III & 240 & 20 & 47.87 & 1.60 & 50.88 & 94.07 & 40 \\
\hline \multirow{6}{*}{$\mathrm{Ni}$} & \multirow{3}{*}{ Yellow } & I & 1054 & 100 & 236.43 & 7.88 & 255.33 & 92.60 & 200 \\
\hline & & II & - & - & - & - & - & - & - \\
\hline & & III & 938 & 50 & 214.45 & 7.15 & 227.23 & 94.38 & 100 \\
\hline & \multirow{3}{*}{ Red } & I & 1030 & 90 & 235.48 & 7.85 & 249.52 & 94.38 & 180 \\
\hline & & II & - & - & - & - & - & - & - \\
\hline & & III & 538 & 26 & 123.74 & 4.12 & 130.33 & 94.94 & 52 \\
\hline
\end{tabular}

reversible process of the ions on the adsorbent surface during the flow of the distilled water. This could estimate that some metal ions were removed in cycle II. This phenomenon implied that these adsorbents can be recovered for further use. The progression of the concentrations of the effluents in cycle III was virtually similar to cycle I. Its time services $(t)$ to reach the breakthrough points and the point of exhaustion column, however, seemed to be attained earlier than those in cycle I. This finding was attributed to the better availability of the active site in cycle I in comparison with cycle III, and be consistent with the previous studies $[1,13]$. It was observed that the S-shaped curves of adsorption using red loess consisted of the earlier breakthrough points and rose more steeply near the point of the exhaustion column in comparison with using the yellow loess. The appearance of sharper shapes could be due to the smaller mass transfer zone of intraparticle and limited diffusion reasons [21]. The shift of the breakthrough curves from left to right showed the higher removal and efficiency of adsorption [22]. The adsorption capability demonstrated by the breakthrough curve in the right part is normally greater than the left one.

\section{Experimental Analysis}

The data given by the breakthrough curves were computed and analyzed using equations (1) to (6). The summa- rized results of the experimental analysis are indicated in Table 5 .

The effluent volume $\left(V_{\text {eff }}\right)$ is calculated by Eq. (1):

$$
V_{\text {eff }}=Q t_{\text {total }}
$$

Total mass of adsorbate $\left(q_{\text {total }}\right)$ adsorbed at specific column parameters can be defined from Eq. (2):

$$
q_{\text {total }}=\frac{Q}{1000} \int_{0}^{t_{\text {total }}} C_{a d} d t=\frac{Q}{1000}\left(C_{0}-C_{t}\right) t_{\text {total }}(2)
$$

Maximum capacity of the column or equilibrium uptake per unit mass of adsorbent $\left(q_{\text {eq(exp })}\right)$ is calculated as follows:

$$
q_{\text {eq(exp })}=\frac{q_{\text {total }}}{m}
$$

Total amount of adsorbate passing from the column $\left(m_{\text {total }}\right)$ is described as follows:

$$
m_{\text {total }}=\frac{C_{0} Q t_{\text {total }}}{1000}
$$

Total removal percentage of adsorbate $(Y \%)$ is computed in the following equation:

$$
Y(\%)=\frac{q_{\text {total }}}{m_{\text {total }}} \times 100
$$


Empty bed contact time (EBCT) in the column is described as:

$$
E B C T(\min )=\frac{V_{b}}{Q}
$$

...where $t_{\text {total }}$ is the total flow time ( $\left.\mathrm{min}\right), Q$ is the flow rate $(\mathrm{mL} / \mathrm{min}), C_{0}$ is the concentration of the influents $(\mathrm{mg} / \mathrm{L})$, $C_{t}$ is the concentration of the effluents $(\mathrm{mg} / \mathrm{L}), C_{a d}$ is the adsorbed heavy metal concentration $(\mathrm{mg} / \mathrm{L}), m$ is the mass of adsorbent packed in the column (g), and $V_{b}$ is the bed volume.

The empty bed contact time $(E B C T)$ and the total service times $\left(t_{\text {total }}\right)$ in cycle I were more time-consuming than those in cycle III. The total mass of the adsorbates $\left(q_{\text {total }}\right)$ and the maximum capacity per unit mass of the adsorbents
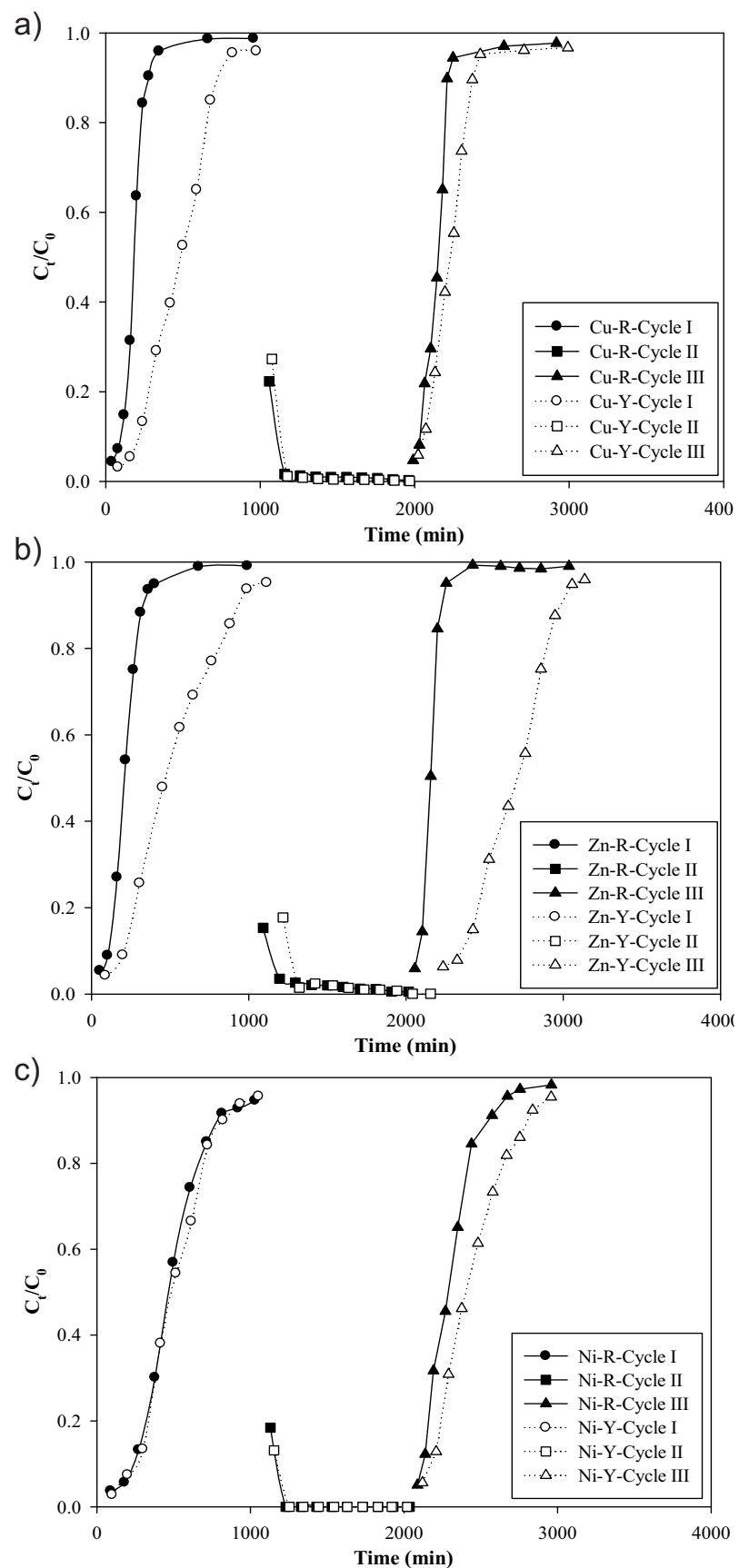

Fig. 5. Breakthrough curves of $\mathrm{Cu}, \mathrm{Zn}$, and $\mathrm{Ni}$.
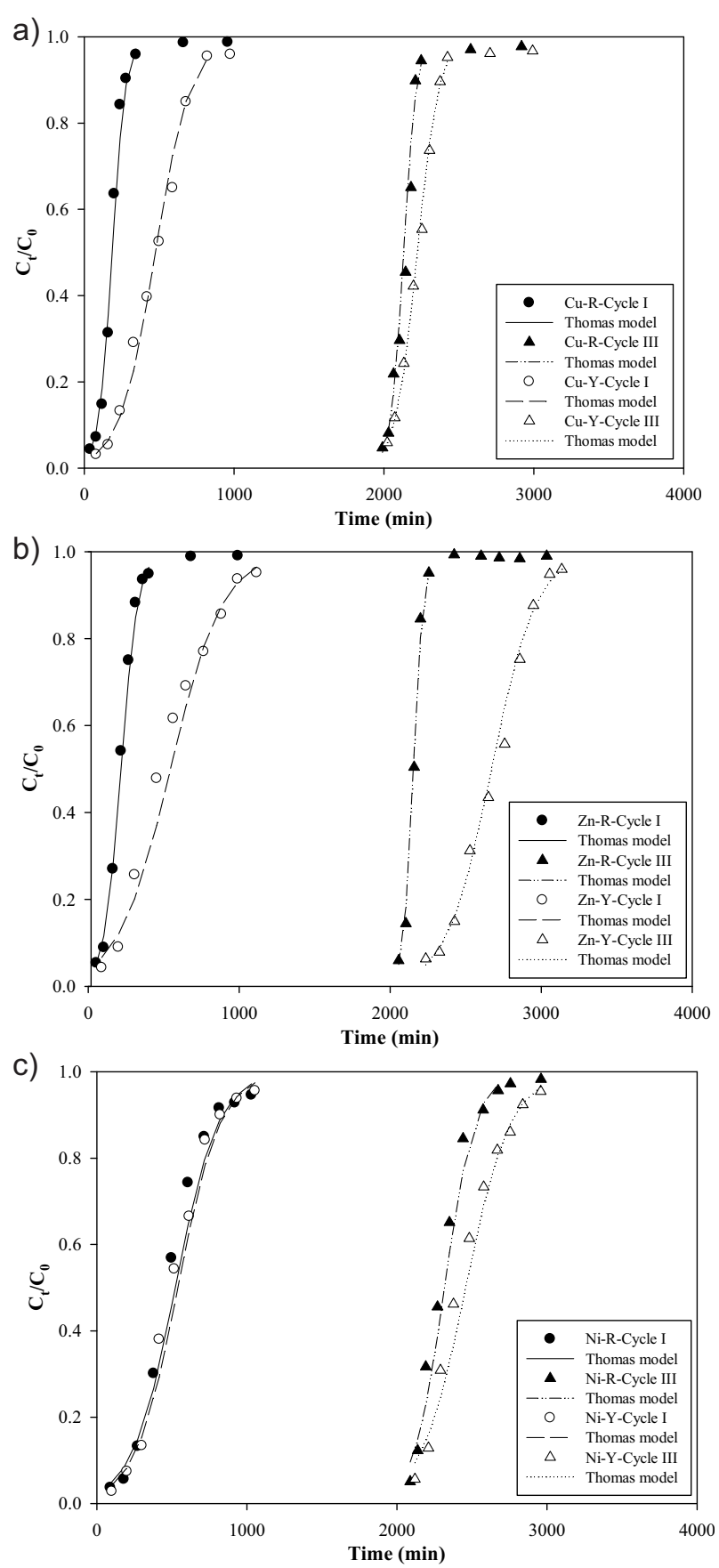

Fig. 6. Modeled breakthrough curves by Thomas model.

$\left(q_{\text {eq(exp })}\right)$ in cycle I simultaneously were greater than those in cycle III. The incomplete desorption process in cycle II probably leads to the reduction of adsorption efficiency in cycle III. The adsorption of cycle I in this study is likely to have physical forces. This could be certified that some amounts of the adsorbed metals were still present on the surface of the adsorbents after the desorption process in cycle II. The existence of these adsorbed metals may lessen the adsorption capability in cycle III. The total removal percentage of both adsorbents was superior to $90 \%$. This could be assumed that the adsorbents with the mass of $30 \mathrm{~g}$ could nearly reach complete removal of the heavy metal ions of the initial concentration of $500 \mathrm{mg} / \mathrm{L}$ by applying a flow rate of $0.5 \mathrm{~mL} / \mathrm{min}$. 
Table 6. Parameters of Thomas model and Yoon-Nelson model.

\begin{tabular}{|c|c|c|c|c|c|c|c|c|}
\hline \multirow{2}{*}{ Metals } & \multirow{2}{*}{ Loesses } & \multirow{2}{*}{ Cy. } & \multicolumn{3}{|c|}{ Thomas model } & \multicolumn{3}{|c|}{ Yoon-Nelson model } \\
\hline & & & $k_{T H}(\mathrm{~L} / \mathrm{min} \cdot \mathrm{mg})$ & $q_{0}(\mathrm{mg} / \mathrm{g})$ & $\mathrm{R}^{2}$ & $k_{Y N}\left(\min ^{-1}\right)$ & $\mathrm{T}(\min )$ & $\mathrm{R}^{2}$ \\
\hline \multirow{6}{*}{$\mathrm{Cu}$} & \multirow{3}{*}{ Yellow } & I & $1.71 \times 10^{-5}$ & 3.93 & 0.991 & 0.009 & 475.31 & 0.991 \\
\hline & & II & - & - & - & - & - & - \\
\hline & & III & $2.80 \times 10^{-5}$ & 2.10 & 0.995 & 0.014 & 253.46 & 0.996 \\
\hline & \multirow{3}{*}{ Red } & I & $4.47 \times 10^{-5}$ & 1.54 & 0.968 & 0.022 & 186.658 & 0.969 \\
\hline & & II & - & - & - & - & - & - \\
\hline & & III & $4.67 \times 10^{-5}$ & 1.42 & 0.969 & 0.023 & 171.220 & 0.969 \\
\hline \multirow{6}{*}{$\mathrm{Zn}$} & \multirow{3}{*}{ Yellow } & I & $1.36 \times 10^{-5}$ & 3.86 & 0.974 & 0.006 & 545.69 & 0.974 \\
\hline & & II & - & - & - & - & - & - \\
\hline & & III & $1.60 \times 10^{-5}$ & 3.64 & 0.991 & 0.007 & 514.55 & 0.991 \\
\hline & \multirow{3}{*}{ Red } & I & $4.22 \times 10^{-5}$ & 1.54 & 0.989 & 0.018 & 216.33 & 0.989 \\
\hline & & II & - & - & - & - & - & - \\
\hline & & III & $7.09 \times 10^{-5}$ & 0.97 & 0.989 & 0.030 & 137.70 & 0.990 \\
\hline \multirow{6}{*}{$\mathrm{Ni}$} & \multirow{3}{*}{ Yellow } & I & $1.46 \times 10^{-5}$ & 4.36 & 0.978 & 0.007 & 540.00 & 0.978 \\
\hline & & II & - & - & - & - & - & - \\
\hline & & III & $1.38 \times 10^{-5}$ & 3.54 & 0.972 & 0.007 & 437.79 & 0.972 \\
\hline & \multirow{3}{*}{ Red } & I & $1.44 \times 10^{-5}$ & 4.22 & 0.969 & 0.007 & 522.54 & 0.969 \\
\hline & & II & - & - & - & - & - & - \\
\hline & & III & $2.02 \times 10^{-5}$ & 2.27 & 0.956 & 0.009 & 280.74 & 0.957 \\
\hline
\end{tabular}

The late attainment of the breakthrough point and the point of exhaustion of column by using yellow loess as the adsorbents in comparison with those by the red loess illuminated a significant difference of their adsorption capacities. The uptake capacities of yellow loess were found greater than those of the red one. The surface areas of the yellow and red were respectively equal to $18.84 \mathrm{~m}^{2} / \mathrm{g}$ and $8.00 \mathrm{~m}^{2} / \mathrm{g}$. This phenomenon corresponded to the amount of the adsorbing site during the adsorption process. It was observed that the higher surface area of the adsorbents offers more adsorption efficiency and capacity. The maximum adsorption capacities per unit mass of the adsorbents were in the order of $\mathrm{Cu}<\mathrm{Zn}<\mathrm{Ni}$.

\section{Theoretical Analysis}

Some mathematical models have been developed to predict the dynamic behavior of the column. The YoonNelson and Thomas models were applied to determine the behavior of the breakthrough curves in this study [23, 24].

The Thomas Model was selected to evaluate the adsorption capacity of the adsorbent in a fixed bed column and is mathematically expressed as follows:

$$
\frac{C_{t}}{C_{0}}=\frac{1}{1+\exp \left(\frac{k_{T H} q_{0} m}{Q}-k_{T H} C_{0} t\right)}
$$

...where $k_{T H}$ is the Thomas rate constant $(\mathrm{mL} / \mathrm{min} \mathrm{mg})$ and $q_{0}$ is adsorption capacity $(\mathrm{mg} / \mathrm{g})$.

The Thomas rate constant $\left(k_{T H}\right)$ and the adsorption capacity $\left(q_{0}\right)$ obtaining from the linearized form of the Thomas Model are calculated based on the following equation:

$$
\ln \left(\frac{C_{0}}{C_{t}}-1\right)=\frac{k_{T H} q_{0} m}{Q}-k_{T H} C_{0} t
$$

Figs. 6 (a), (b), and (c) correspondingly illustrate the breakthrough curves conforming to the application of the Thomas Model. The coordinates of those modeled breakthrough curves were given by the computation of Eq. 7. The correlation coefficients $\left(\mathrm{R}^{2}\right)$ ranging between 0.956 and 0.995 show a good fitting trend of the Thomas Model to predict the adsorption capacity. These theoretical results were in good agreement with the experimental ones. This confirmed the applicability of this model to describe the experimental data. The parameters of the Thomas Model are described in Table 6. 
Yoon and Nelson established a fixed bed adsorption kinetic model based on the assumption that the rate of decrease in the probability of adsorption for each adsorbate molecule is proportional to the probability of adsorbate adsorption and the probability of adosorbate breakthrough on the adsorbent. The linearized Yoon-Nelson Model is in the following equation:

$$
\ln \left(\frac{C_{t}}{C_{0}-C_{t}}\right)=k_{Y N} t-k_{Y N} \tau
$$

...where $k_{Y N}$ is the rate constant $\left(\mathrm{min}^{-1}\right), \tau$ is the time required for $50 \%$ adsorbate breakthrough $(\mathrm{min})$, and $t$ is the processing time ( $\mathrm{min})$.

Yoon-Nelson was applied to address the breakthrough behavior in this study. The parameters of Yoon-Nelson are described in Table 6 . The time required for $50 \%$ adsorbate breakthrough given by Yoon-Nelson was approximately found in half of the total times. This parameter refers to the time interval in which the adsorbents can adsorb half the amount of total adsorption capacity. It was seen that the correlation coefficients $\left(\mathrm{R}^{2}\right)$ ranged from 0.956 to 0.995 . This eventually showed that Yoon-Nelson can be found to be satisfactory to predict the breakthrough behavior in this study.

\section{Conclusion}

The breakthrough curves representing the adsorption process ultimately identified the adsorption behaviors in this research. The adsorption capabilities in cycle I appeared to be much greater than those in cycle III. The desorption process in cycle II could not fully remove the adsorbed metal ions from the surface of the adsorption. Distilled water should be replaced by other reagents (HCL or $\mathrm{NAOH}$ ) to reach the complete removal of the adsorbed metals. Yellow loess depicted great adsorption capacities for all cases in comparison with the red loess. The higher surface area becomes a crucial parameter affecting the adsorption capacity. The value of the correlation coefficients $\left(\mathrm{R}^{2}\right)$ identified that Thomas and Yoon Nelson could properly predict the adsorption behaviors in this study. The wastewater treatment reservoir can be developed by using loesses as the adsorbents with Standard Proctor Compaction.

\section{Acknowledgements}

The authors are grateful to Dr. Noppadol Sangiumsak for his collaboration and to the Faculty of Dentistry of Khon Kaen University for SEM examination. This research was funded by the Sustainable Infrastructure, Research and Development Center (SIRDC), Faculty of Engineering, Khon Kaen University.

\section{References}

1. BHAUMIK M., SETSHEDI K., MAITY A., ONYANGO M.S. Chromium(VI) removal from water using fixed bed column of polypyrrole $/ \mathrm{Fe}_{3} \mathrm{O}_{4}$ nanocomposite. Sep. Purif. Technol. 110, 11, 2013.

2. LAROUS S., MENIAI A.H., LEHOCINE M.B. Experimental study of the removal of copper from aqueous solutions by adsorption using sawdust. Desalination. 185, (1-3), 483, 2005.

3. BARRELL D.C. Atomic Spectrophotometer Analysis of Heavy Metals Pollutants in Water. Ann Arbor Science Publishers Inc: Ann Arbor, 1975.

4. MEENA A.K., MISHRA G.K., RAI P.K., RAJAGOPAL C., NAGAR P.N. Removal of heavy metal ions from aqueous solutions using carbon aerogel as an adsorbent. J. Hazard. Mater. 122, (1-2), 161, 2005.

5. SITTING M. Toxic Metals-Pollution Control and Worker Protection. Noyes Data Corporation: New Jersey, 1976.

6. GURGEL L.V.A., PERIN DE MELO J.C., DE LENA J.C., GIL L.F. Adsorption of chromium (VI) ion from aqueous solution by succinylated mercerized cellulose functionalized with quaternary ammonium groups. Bioresour. Technol. 100, (13), 3214, 2009.

7. OLGUN A., ATAR N., WANG S. Batch and column studies of phosphate and nitrate adsorption on waste solids containing boron impurity. Chem. Eng. J. 222, 108, 2013.

8. PACHECO S., MEDINA M., VALENCIA F., TAPIA J. Removal of Inorganic Mercury from Polluted Water Using Structured Nanoparticles. J. Environ. Eng. 132, (3), 342, 2006.

9. PEHLIVAN E., CETIN S. Sorption of Cr(VI) ions on two Lewatit-anion exchange resins and their quantitative determination using UV-visible spectrophotometer. J. Hazard. Mater. 163, (1), 448, 2009.

10. OWLAD M., AROUA M.K., DAUD W.A.W., BAROUTIAN S. Removal of hexavalent chromium-contaminated water and wastewater: a review. Water, Air, Soil Pollut. 200, (1-4), 59, 2009.

11. XU X., GAO B., TAN X., ZHANG X., YUE Q., WANG Y., LI Q. Nitrate adsorption by stratified wheat straw resin in lab-scale columns. Chem. Eng. J. 226, 1, 2013.

12. AL-DEGS Y.S., KHRAISHEH M.A.M., ALLEN S.J., AHMAD M.N. Adsorption characteristics of reactive dyes in columns of activated carbon. J. Hazard. Mater. 165, (1-3), 944, 2009.

13. LI W., YUE Q., TU P., MA Z., GAO B., LI J., XU X. Adsorption characteristics of dyes in columns of activated carbon prepared from paper mill sewage sludge. Chem. Eng. J. 178, 197, 2011.

14. SANGIUMSAK N., PUNRATTANASIN P. Adsorption Behavior of Heavy Metals on Various Soils. Pol. J. Environ. Stud. 23, (3), 853, 2014.

15. PUNRATTANASIN P., SARIEM P. Adsorption of Copper, Zinc, and Nickel Using Loess as Adsorbents. Pol. J. Environ Stud. 24, (3), 1259, 2014.

16. HUANGJING S., GASALUCK W. The Stabilization of Loess by Chemical Additives for Road Base. The Electronic Journal of Geotechnical Engineering, 15, 1651, 2010.

17. PHIEN-WEJ N., PIENTONG T., BALASUBRAMANIAM A.S., Collapse and strength characteristics of loess in Thailand. Eng. Geol. 32, (1-2), 59, 1992.

18. WANG Y., TANG X., CHEN Y., ZHAN L., LI Z., TANG Q. Adsorption behavior and mechanism of Cd(II) on loess soil from China. J. Hazard. Mater. 172, (1), 30, 2009.

19. AHMAD A.A., HAMEED B.H. Fixed-bed adsorption of reactive azo dye onto granular activated carbon prepared from waste. J. Hazard. Mater., 175, (1-3), 298, 2010. 
20. HAN R., WANG Y., ZHAO X., WANG Y., XIE F., CHENG J., TANG M. Adsorption of methylene blue by phoenix tree leaf powder in a fixed-bed column: experiments and prediction of breakthrough curves. Desalination. 245, (1-3), 284, 2009.

21. BRUNSON L.R., SABATINI D.A. Practical considerations, column studies and natural organic material competition for fluoride removal with bone char and aluminum amended materials in the Main Ethiopian Rift Valley. Sci. Total Environ. 2013.
22. ALBADARIN A.B., MANGWANDI C., AL-MUHTASEB A.H., WALKER G.M., ALLEN S.J., AHMAD M.N.M. Modelling and Fixed Bed Column Adsorption of $\mathrm{Cr}(\mathrm{VI})$ onto Orthophosphoric Acid-activated Lignin. Chin. J. Chem. Eng. 20, (3), 469, 2012.

23. YOON Y.H., NELSON J.H. Application of gas adsorption kinetics. I a theorical model for respirator catridge service time. Am. Ind. Hyg. Assoc. J. 45, 509, 1984.

24. THOMAS H.C. Hererogeneous ion exchange in a flowing system. J. Am. Chem. Soc. 66, 664, 1944. 
